\title{
CAVE EXPLORATION AS A GUIDE TO GEOLOGIC RESEARCH IN THE APPALACHIANS
}

\author{
Arthur N. Palmer \\ Department of Earth Sciences, State University of New York, Oneonta, NY 13820, palmeran@oneonta.edu
}

\begin{abstract}
Cave exploration and mapping can provide considerable insight into the nature of groundwater flow and geologic processes in soluble rocks. The Appalachian Mountains provide an ideal setting for this exchange of information because their geology varies greatly over short distances. Caves reveal the way in which groundwater flow is guided by geologic structure, and they help to clarify aquifer test data, well yield, and contaminant dispersion. Well tests in karst aquifers often reveal confined or unconfined conditions that make little sense stratigraphically, but which can be explained with the aid of cave mapping. With regard to geologic mapping, many caves reveal structures that are not visible at the surface. Caves also show evidence for underground geochemical processes that cannot be detected from well data. Subtle mineralogical clues are generally erased by weathering and erosion at the surface, but persist in many caves. The information that caves have provided about subsurface geology and water flow is now being used by explorers, even those with no geologic background, to help them find new caves.
\end{abstract}

DOI: $10.4311 /$ jcks2008es0042

\section{INTRODUCTION}

A century ago, not much was known about Appalachian caves and their patterns, and the few available cave maps revealed little about the local geology or regional context. As exploration accelerated in the mid-1900s, a wide variety of cave maps became available, and the relation between caves and their surroundings became clearer. In many of the studies from this period, the main application of cave data was its integration with surface geomorphology (see Kambesis, 2007; and White, this volume). In this paper, I follow a different direction to show how cave data can apply to processes that are only indirectly related to the surface. The topics of special interest here include groundwater hydrology, subsurface geologic structure, and geochemistry. Only solution caves are considered here, because they provide the greatest amount of information about water flow and its control by geologic structure.

\section{Appalachian Geology}

The Appalachians provide a world-class example of continental-edge tectonic deformation. Their special virtue for cave studies is that they provide a broad variety of geology, landscapes, and cave types. From southeast to northwest, the rocks grade from igneous and metamorphic to sedimentary and from complex to rather simple structure. The region consists of several physiographic regions (Fig. 1): from east to west they are (1) the Piedmont Province, which consists of igneous and highly deformed metamorphic rocks exposed in low hills; (2) the Blue Ridge Province, which is a highland composed of resistant sedimentary and metamorphic rocks; (3) the
Ridge and Valley Province, which consists of folded and faulted sedimentary rocks; and (4) the Appalachian Plateaus Province, a broad, high upland composed of mostly flat-lying sedimentary rocks. In the northeast, the New England Province is a broad mountainous region geologically related to the Piedmont, and the Adirondack Province is a local mountainous uplift of relatively old igneous and metamorphic rocks.

Metamorphic rocks of the Piedmont include marbles of Cambrian-Ordovician age. These were deformed by several phases of Appalachian mountain building throughout much of the Paleozoic Era. In hilly regions, the marbles are exposed in narrow discontinuous bands, but they contain significant caves only in the northeastern equivalent of the Piedmont in western New England and eastern New York. The Adirondack Mountains of northern New York include the ancient, highly crystalline Grenville Marble around their perimeter. The metamorphism took place during the massive Grenville deformation (about 1.2 billion years ago during the Precambrian Era) of even older carbonate strata. The Grenville contains many caves, none very extensive, but some with large passage cross sections where there has been abundant groundwater flow.

The Blue Ridge Province is the western boundary of the Piedmont. It consists of resistant sandstones and metamorphic rocks of Precambrian and lower Cambrian age that stand as a high ridge or upland separating the lowlands of the Piedmont from the lowlands of Cambrian-Ordovician limestones of the Ridge and Valley Province to the west. It widens southward into the Smoky Mountains, which include the highest peaks east of the Mississippi. There are no significant soluble rocks in this province.

The Ridge and Valley Province includes strongly folded limestones and dolomites, interspersed with insoluble 


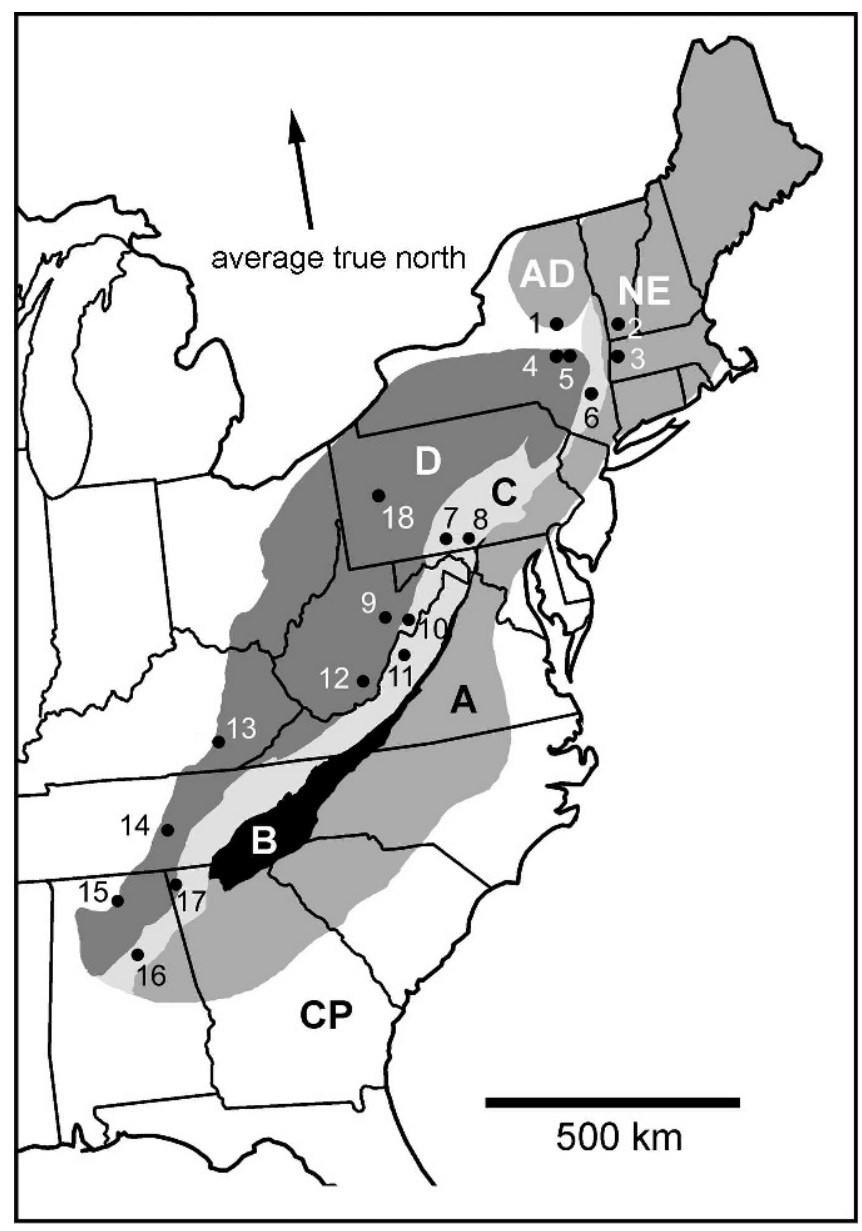

Figure 1. Map of the Appalachian Mountains, showing geomorphic provinces and field sites described in this paper. A = Piedmont Province; $\mathbf{B}=$ Blue Ridge Province; $\mathbf{C}=$ Ridge and Valley Province; $\mathrm{D}=$ Appalachian Plateaus Province; NE = New England Province (continuous with Piedmont Province); $\mathrm{AD}=$ Adirondack Province, a window of igneous and metamorphic rocks dating from the Precambrian Grenville Orogeny; $\mathbf{C P}=$ Coastal Plain, consisting of gently dipping sedimentary rocks of Cenozoic age. $1=$ Carter Ponds Cave, N.Y.; 2 = Morris Cave, Vt., 3 = Convention Cave, Mass.; 4 = caves of Schoharie County, N.Y.; $5=$ Knox Cave, N.Y.; $6=$ Jack Packer's Cave, N.Y.; 7 = Hipple Cave, Pa.; 8 = Goods Cave, Pa.; 9 = Marshall Cave, W.Va.; 10 = Minor Rexrode Cave, W.Va.; 11 = Butler and Clark's Caves, Va.; 12 = Culverson Creek, Ludington, and Burnside Branch Caves, W.Va.; 13 = Wells Cave, Ky.; 14 = Blue Spring, Camp's Gulf, and Rumbling Falls Caves, Tenn.; 15 = Anvil Cave, Ala.; 16= Anderson Cave, Ala.; $17=$ Ellison Cave, Ga.; $18=$ Harlansburg Cave, Pa.

rocks, all of which have been strongly folded and faulted. Differential resistance of the eroded rocks has formed ridges and valleys that are strongly linear and parallel. Carbonate rocks are exposed in valleys and ridge flanks and are highly cavernous. Most of the strata are of early
Paleozoic age. A broad valley of thick Cambrian-Ordovician carbonates extends along the eastern edge of the province, but because of the low-relief terrain, most caves are small and scattered.

The Appalachian Plateaus consist of less deformed Paleozoic strata that stand as high, dissected plateaus. Folding and faulting are common along the eastern side and account for a few broad ridges and valleys, but otherwise, the topography is dominated by deep dendritic valleys with intervening uplands. Carbonate rocks range from Cambrian to Mississippian age.

\section{Effect of Geologic Structure on Groundwater Flow PatTerns}

The way in which water flows through cavernous rock may seem indecipherable from water-well data, but a familiarity with caves can remove much of the confusion. Solution caves form along the paths of maximum groundwater flow, so an accurate cave map shows which of the local recharge patterns and geologic structures have been most important in determining the flow patterns and, therefore, potential routes for contaminant dispersion.

Appalachian cave patterns strongly reflect variations in the geologic structure. Figure 2 shows some representative cave patterns in each province. Comparing caves of vastly different scale can be misleading, but the general tendencies are clear from those shown in the figure.

In the highly deformed marbles of New England and the Adirondacks (Fig. 3), the caves follow irregular paths along several fault and joint systems, sheet fractures parallel to the land surface, and metamorphic foliation. The original stratal dips are indistinct in many areas, and highly varied where detectable. Groundwater moves opportunistically through all of these openings in the direction of the main lines of underground drainage. Small caves of similar, but structurally less complex, patterns are also scattered throughout the other provinces, especially where floodwater has formed or modified them. It is often not possible from the maps alone to make a clear distinction between caves in the northeastern marbles and caves in other provinces.

In the strongly folded Ridge and Valley Province, most caves have greatly elongate patterns that follow the linear trends of the topography, parallel to the strike of the beds (Fig. 4). Examples in Figure 2e-h show that many caves of small to moderate size throughout the full length of the region consist almost entirely of single strike-oriented passages. Many caves, especially large ones such as Figure 2d, are complicated by diversion passages and down-dip tributaries, and yet, the overall strike orientation is still clear. Network caves are also common in this region, mainly in local areas of nearly horizontal, highly jointed beds capped by thin, permeable sandstone.

Most of the Appalachian Plateaus Province contains faintly deformed strata, although folding and faulting are 


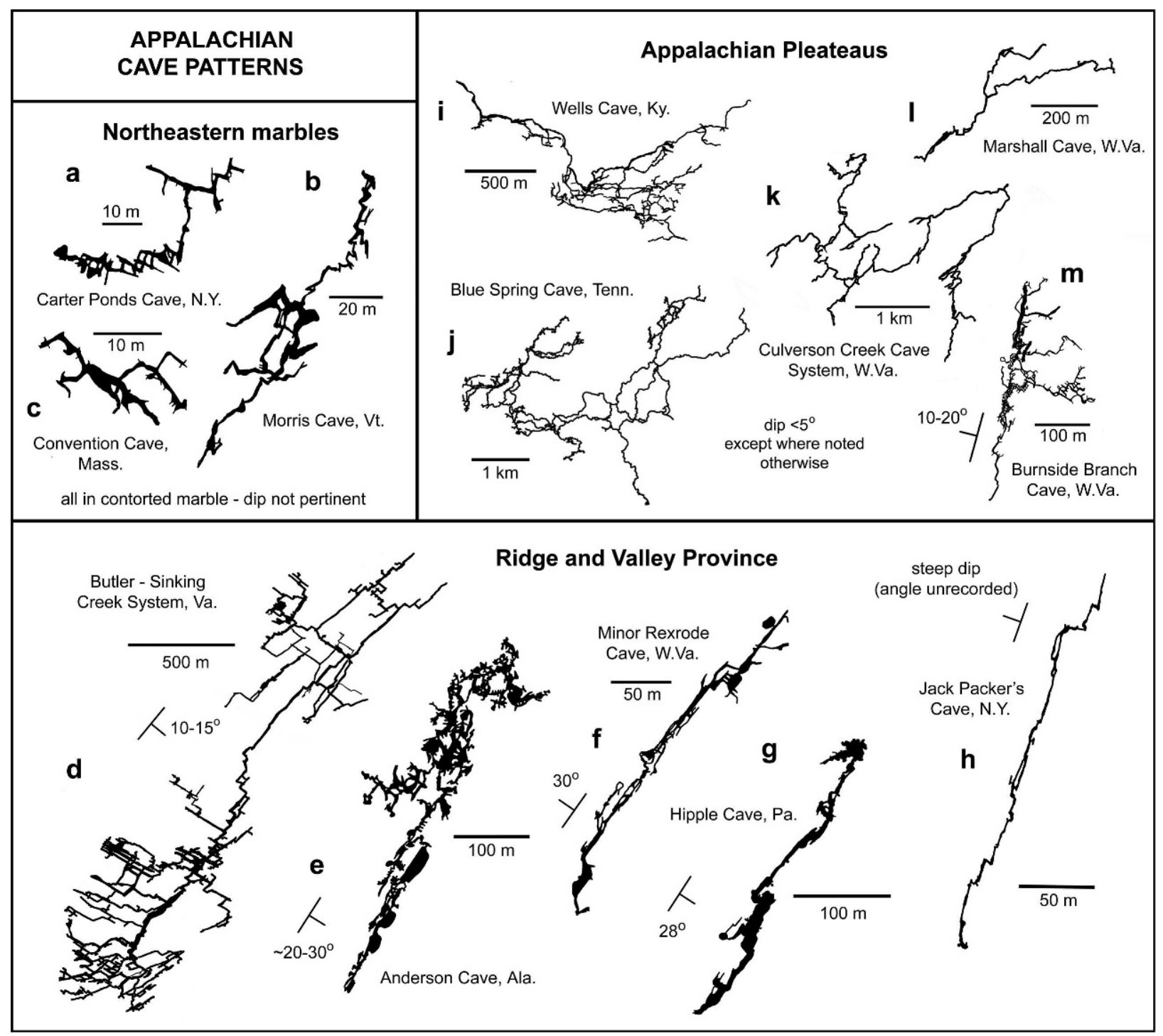

Figure 2. Typical cave patterns in the Appalachians. Maps simplified from the following: Piedmont equivalent (marbles of western New England and foothills of Adirondack Mountains: (a) Porter (2002); (b) P. Quick et al. (Nardacci, 1991); (c) J. Wells et al. (Nardacci, 1991). Ridge and Valley Province: (d) = Butler Cave Conservation Society; (e) E. Breeland et al. (Varnedoe, 1973); (f) W. Davies (1958); (g) B. Smeltzer (Stone, 1953); (h) D. Brison et al. (Nardacci, 1991). Appalachian Plateaus Province: (i) Dayton Area Speleological Society; (j) W. Walter et al. (data from M. Yocum); (k) West Virginia Association for Cave Studies; (l) D. Medville et al. (Dasher, 2000); (m) P. Williams et al. (Haar et al., 1975). See text for discussion of cave patterns.

common along its southeastern border with the Ridge and Valley Province. Mississippian limestones are exposed over broad areas, especially around the margins of the plateaus. Most caves have broad, curving patterns guided mainly by the bedding of the strata (Fig. 2i-1; Fig. 5). Where dips are low, the dip and strike still play an important role in cave patterns, but subtle variations in dip direction make this relationship unclear. In contrast, the cave in Figure $2 \mathrm{~m}$ is located along the gently folded southeastern edge of the Appalachian Plateaus, where the main passages are tightly aligned along the strike and dip-oriented tributaries join from the east (compare with Fig. 2d). Network caves are also scattered throughout the Appalachian Plateaus; as in the Ridge and Valley Province, they are located in highly jointed, nearly horizontal strata capped by thin sandstone. Maze caves of this sort are described in a later section.

As is typical in many caves throughout the world, passages in Appalachian caves that formed in the vadose zone (above the water table) tend to follow the dip of the rocks, whereas those that formed in the phreatic zone (at or below the water table) are strongly influenced by the strike of the beds. The steeper the dip, the shorter and more linear are the vadose passages, and the longer and more linear are the phreatic passages. From most cave maps it is possible 


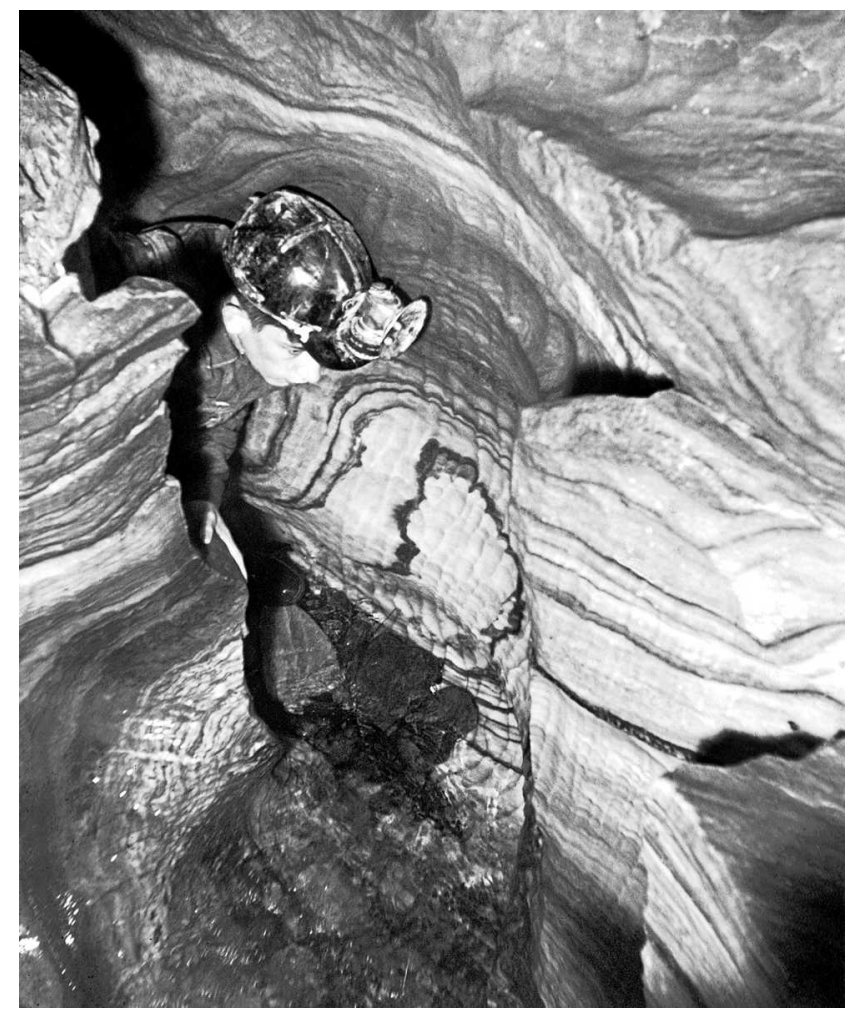

Figure 3. Contorted marble in an overturned syncline, Eldon's Cave, Massachusetts, in the New England extension of the Piedmont Province.

to interpret the local rock structure from these criteria alone. In most marble caves, this relationship is insignificant, however, because the original stratal dip is indistinguishable. Large sheet fractures may serve the same function on a local scale.

Although it is easy to overestimate the value of these observations to groundwater science, cave patterns still provide insight that is difficult to obtain in other ways. One who is familiar with them can at least anticipate broad trends in well yield and contaminant dispersion, or find the appropriate words to describe what is observed from well tests.

\section{Directional Permeability (Anisotropy) in Karst Aquifers}

In characterizing an aquifer for water supply, one of the first things to consider is whether it behaves in a confined or unconfined manner. In a confined aquifer, the potentiometric surface (level at which water stands in a non-pumping well) lies in low-permeability beds above the aquifer. Water moves parallel to the top and bottom of the aquifer. In an unconfined aquifer, there is no confining bed, and water is free to move vertically, as well as parallel, to the aquifer boundaries. The difference between the two aquifer types, shown in Figure 6, is important in predicting well yield and anticipating contaminant leakage from the surface.

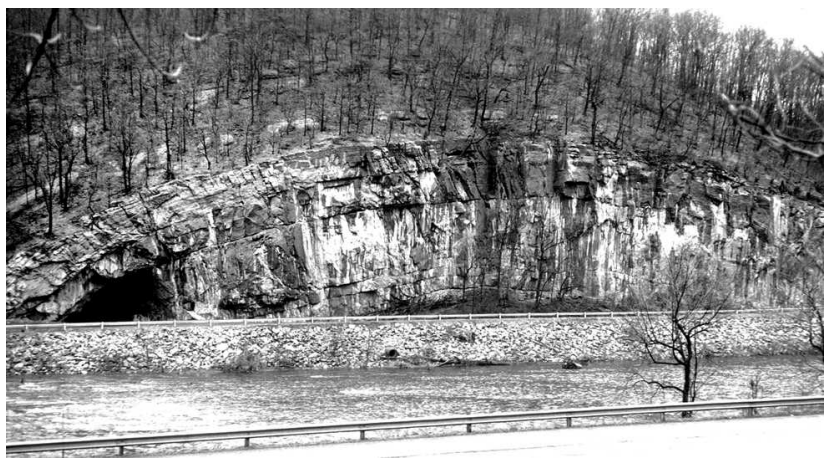

Figure 4. Opening to a strike-oriented cave along the flank of an anticline, Island Ford Cave, Virginia, in the Ridge and Valley Province. (Cave entrance is the dark triangular area on left.)

By observing water movement through caves, it is immediately clear that there is a very hazy distinction between the two aquifer types in soluble rock, and apparently most bedrock of any kind. Consider the following examples:

\section{Vertical Anisotropy}

In a confined aquifer, the declining water level (drawdown) in a pumping well follows a distinct pattern. After a few minutes of pumping, the drawdown increases linearly with the log of time (see, for example, Fetter, 2001, p. 175). In an unconfined aquifer, the drawdown curve becomes steeper with time and does not plot as a straight line on the graph of drawdown vs. log of time. But in many wells in unconfined soluble rocks, the wells behave as though they were confined. Figure 7 shows an example from a clearly unconfined Silurian-Devonian limestone aquifer, in a well a few hundred meters from McFail's Cave, New York, which lies in the same rock unit. The well terminates at or near the base of the limestone. The straight line on the drawdown graph shows that the flow behaves as though it were in a confined aquifer, i.e., with the flow moving toward the well with no vertical convergence during the period of pumping.

This is unexpected, because many caves in the region are strongly guided by vertical joints, which illustrates the prominent role of fractures discordant to the bedding. But, although there are prominent joints in the uppermost limestone unit (Coeymans Limestone), the cave passages in the underlying Manlius Limestone are sinuous and curvilinear, which shows the strong influence of bedding (Fig. 7). In the Manlius Limestone, this bedding control is interrupted in only a few places by joint-controlled passage segments. The confined behavior of the aquifer, as shown by the well test, is apparently imposed by the prominent bedding. This aquifer is anisotropic; in other words, the horizontal permeability of the Manlius Limestone is greater than the vertical permeability, at least at this location.

Journal of Cave and Karst Studies, December 2009•183 


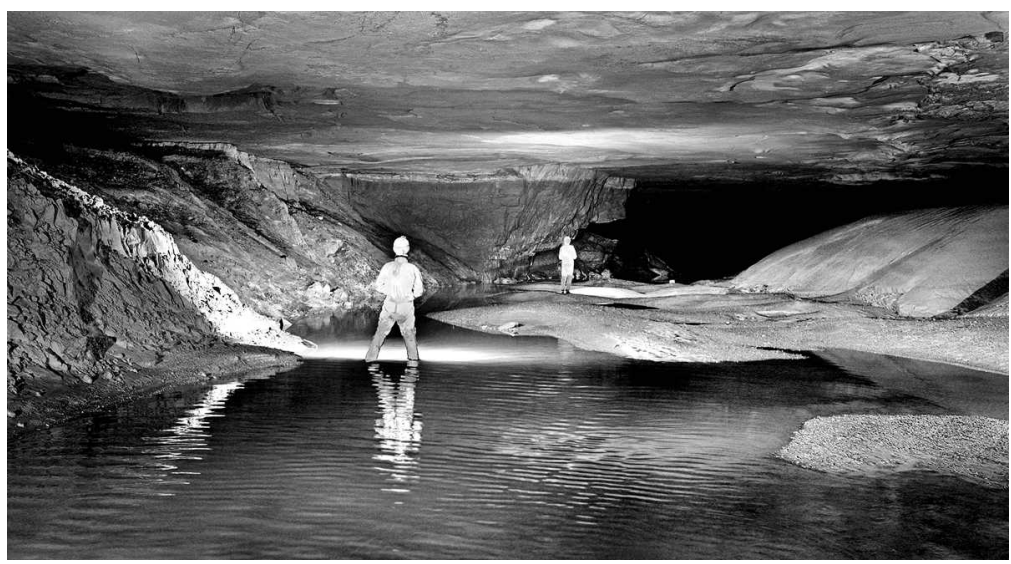

Figure 5. Sinuous bedding-controlled passage in Rumbling Falls Cave, Tennessee, in the Appalachian Plateaus Province.

\section{Horizontal Anisotropy}

In many places in the Appalachians, the elongation of cave patterns suggests that the aquifers are horizontally anisotropic (i.e., that the permeability is greater in one direction than in others). Consider, for example, the elongate patterns of caves in the Ridge and Valley Province (Fig. 2), which suggests that the greatest permeability is in the NE-SW direction. Figure 8 shows an example in southcentral Pennsylvania. Like others in the area, it is a maze cave that provides an indication of the relative importance of two sets of fractures. The strike-oriented fractures are dominant. The rose diagram of passage trends vs. length quantifies this relationship.

An extensive well test was performed in a nearby area by a hydrologic consultant, and the resulting cone of depression, drawn by contouring software, is shown in map view in

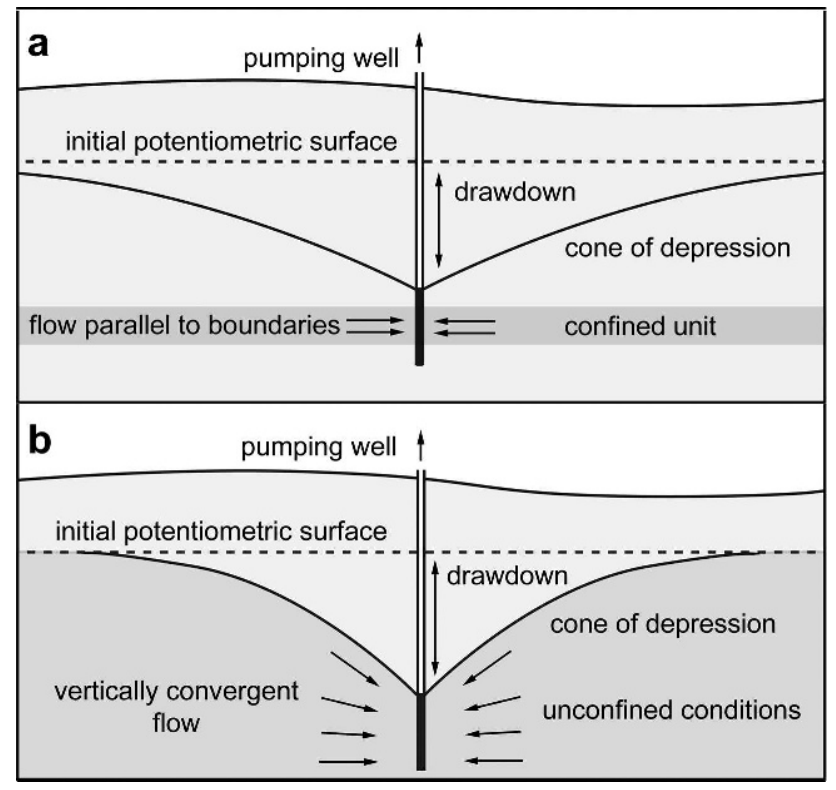

Figure 6. Comparison between confined (a) and unconfined (b) conditions in a pumping well.

184 - Journal of Cave and Karst Studies, December 2009
Figure 8 . Both the cave and the well are located in steeply dipping, massive carbonates of the Cambrian-Ordovician Beekmantown Group. Relative to the local strike in each area, the elongation of the cone of depression is in the same direction as the rose diagram of the cave. Furthermore, their length-to-width ratios are nearly the same.

The asymmetry of a cone of depression represents an even larger contrast in permeabilities. The permeability contrast (NE-SW vs. NW-SE in this case) equals the square of the ratio of long diameter to short diameter of the cone of depression. In other words, $K_{\max } / K_{\min }=\left(D_{\max } / D_{\min }\right)^{2}$, where $K_{\max }$ and $K_{\min }$ are the maximum and minimum permeabilities and $D_{\max }$ and $D_{\min }$ are the maximum and minimum diameters of the cone. In Figure 8, which shows a diameter ratio of about 3.8 to 1 , the NE-SW permeability is about 14 times greater than the NW-SE permeability. This has a strong influence on local contaminant velocities. Incidentally, this well showed a time-drawdown curve typical of an unconfined aquifer, which indicates that local fractures allow abundant vertical flow.

The rose diagram of the cave shows a diameter ratio of about 4.3 to 1 . If treated in the same way as the cone of depression, it suggests that the NE-SW permeability is about 18 times greater than that in the NW-SE direction. There is no quantitative reason why directional permeability should be revealed exactly by the relative lengths of passages in a cave, but field tests by this author in other geomorphic provinces have verified similar relationships (see also Palmer, 1999, 2007). Anisotropy tests in wells are very scanty, so no other comparisons are possible here. Neither the cave nor the well test are bounded by confining units, and in the massive Beekmantown, the influence of bedding is minor.

Anisotropy is a vital component of any site assessment involving potential contaminants, but detecting it with pumping tests is time consuming and costly, as it requires multiple monitoring wells. Thus, it is often overlooked or assumed not to be present. The use of cave patterns to estimate anisotropy is promising and warrants further investigation. 

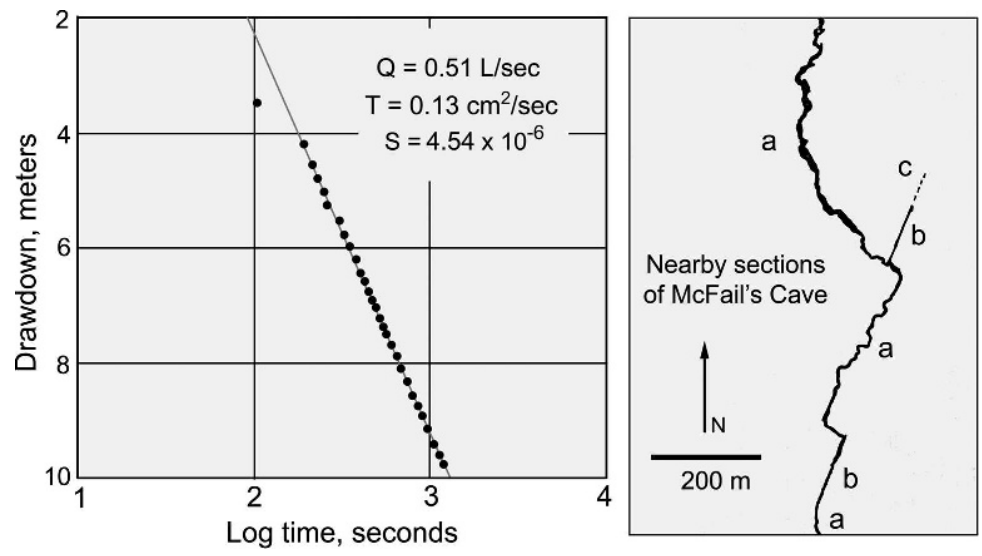

Figure 7. Drawdown graph from pumping of R. Smith well, Schoharie County, N.Y., October 12, 1996. The straight line of the drawdown implies confined aquifer conditions, despite the apparent lack of a confining unit. This shows the vertically constrained nature of water flow in prominently bedded rock. $Q=$ discharge. Transmissivity $(T)$ was calculated from the slope of the line (larger $T$ means higher well yield for a given amount of drawdown). Storativity (S) was calculated from data in an observation well $28.4 \mathrm{~m}$ from pumping well (larger $S$ means smaller volume of cone of depression). Both $T$ and $S$ are very low, as is typical of a non-cavernous limestone. On the cave map, a = sinuous bedding-controlled passages in the Manlius Limestone; $b=$ local joint-controlled fissures in the Manlius Limestone; $c=$ joint-controlled fissures in Coeymans Limestone.

\section{Cryptic Geological Structures}

Geologic mappers acquire most of their information from surface rock exposures, but exposures are widely scattered in the Appalachians because of the thick soil and dense vegetation. Well logs may help, but they provide only local points of information. Caves provide lengthy and continuous exposures that are well suited for stratigraphic and structural mapping. Some examples are described here.

\section{An Active Fault in Georgia}

In 1968, explorers in Ellison's Cave, Georgia, probed into a low, dip-oriented stream passage in the Bangor and Monteagle Limestones (Mississippian age) of Pigeon Mountain, at the eastern edge of the Appalachian Plateaus Province. The passage lies high above the local valleys, partly perched on shale beds. The explorers, led by Richard Schreiber, were approaching the flank of the mountain, but they were still hundreds of meters above the nearby spring outlet. They expected some kind of change in the passage character and were not surprised when the passage floor dropped into a $38-\mathrm{m}$ pit. However, they were stunned when a short distance beyond they found that it plummeted $155 \mathrm{~m}$ (510 ft) straight down along a large fault (Schreiber, 1969). They named it Fantastic Pit. Later exploration showed that the total vertical range from the highest ceiling to the floor is about $200 \mathrm{~m}$.

Off the bottom of the pit, nearly all of the passages follow this fault zone. The orientation of wall grooves (slickensides) shows it to be a lateral fault, with mainly horizontal movement. Many of the fault surfaces are recrystallized to thick sheets of calcite or dolomite (Fig. 9). Most unusual are the piles of pulverized rock that have accumulated from grinding along the fault planes (Fig. 10). This fault has been active recently, at least since the cave formed. Some years after the discovery, a mild earthquake occurred with its epicenter in the center of the same mountain (Richard Schreiber, personal communication, ca. 1988). There has been no apparent damage to the cave, because the fault displacements have been small and intermittent. Still, such an intimate view of a semi-active fault is extremely rare near the land surface, especially in the eastern United States.

\section{Structure in Contact Caves of West Virginia}

The contact caves of southern West Virginia are located at the base of the Greenbrier Group, mainly limestones, where they overlie the soft, mainly insoluble Maccrady Shale along the eastern edge of the Appalachian Plateaus (Dasher, 2000). Both rock units are of Mississippian age. Passages that follow the contact are common in several long caves, such as The Hole, Ludington, McClung, Maxwelton, and Scott Hollow. Cave streams have cut downward into the shale as much as $12 \mathrm{~m}$ in places. The typical contact passage is wide at the top, with a nearly flat ceiling and walls that taper toward each other into a narrow trench (Fig. 11). Any change in dip or displacement along faults is highly visible in the passage ceilings because of the strong contrast in rock types.

At the surface, the low-relief plateaus in which the caves are located show little hint of underlying rock deformation. The caves below display a variety of warps, folds, and faults. For example, in Ludington Cave, many tributaries that enter the main stream passage from the east are developed along the limestone-shale contact. Figure 12 shows the local stratigraphy. An extensive thrust fault cuts 


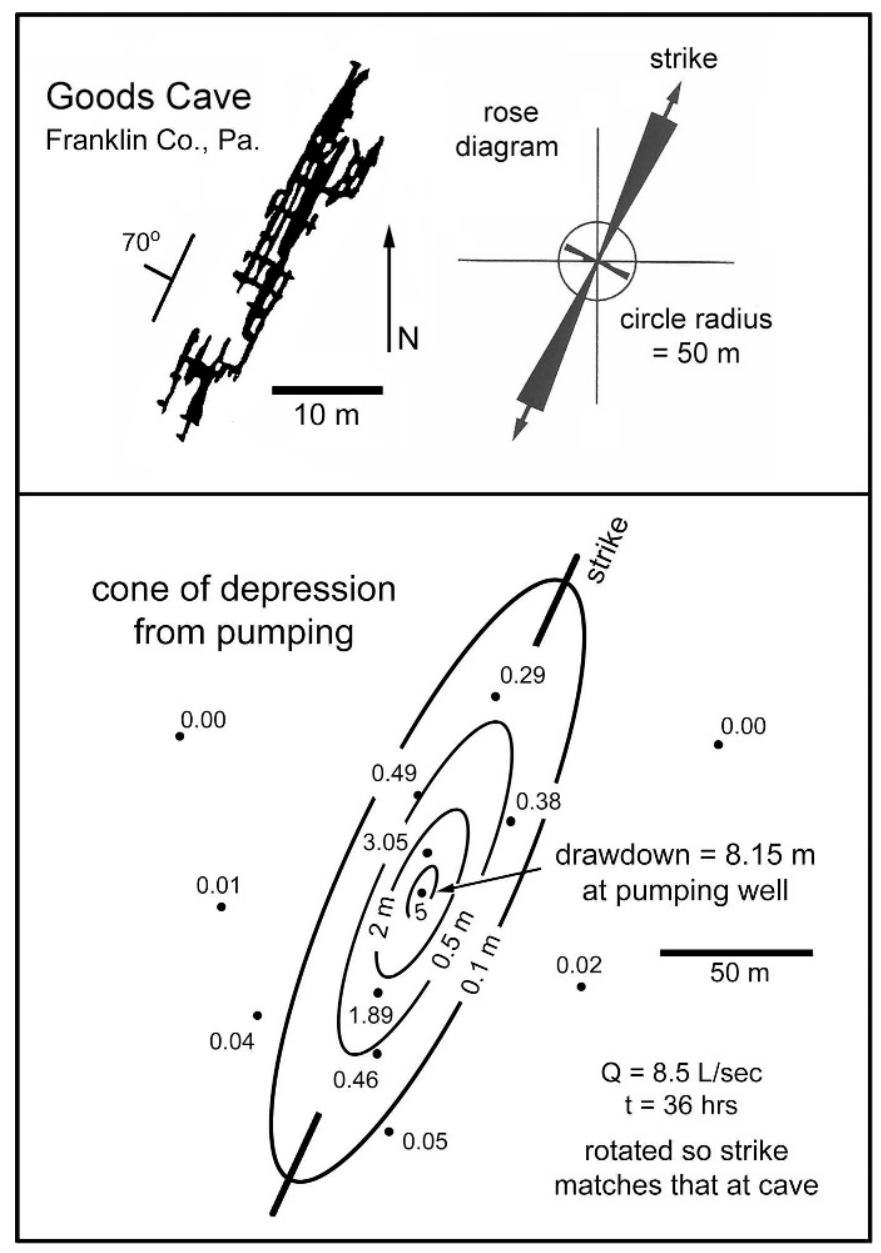

Figure 8. Comparison between the cone of depression in a pumping well in the Beekmantown Group and the rose diagram of passages in a cave in the same strata (Goods Cave, Pa.) in a neighboring county. Cave map by Bernard Smeltzer (from Stone, 1953); well-test data courtesy of John Walker, Doylestown, Pa.

across the beds and follows the contact for a considerable distance (Fig. 13). The underlying beds are shot through with secondary faults, and in places, the beds are dragged upward so that they are vertical or even slightly overturned. The orientations of cave passages in all of the contact caves are adjusted to the structure, with vadose canyons extending down the dipping shale and with local offsets along faults. Few of these structures have been detected at the surface, and their effects on groundwater flow are known only to a handful of speleologists.

\section{Karst Groundwater Flow Along a Fault in Poorly Soluble Rock}

Knox Cave, in Albany County, New York, has been well known for centuries. No major discoveries had been made in it since the late 1950s. Except for a few minor trickles and local streams entering during floods, the cave is fairly dry. Digging in 1995-2000 revealed a new crawlway

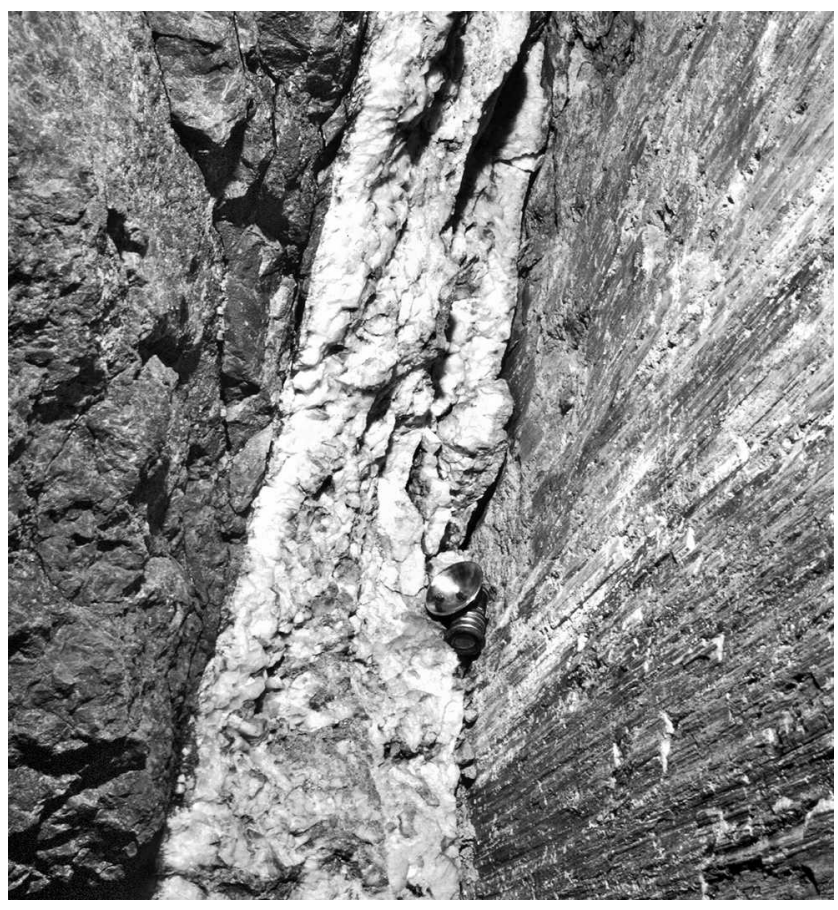

Figure 9. Recrystallized calcite along a fault plane in Ellison Cave, Georgia. Note the slickensides that indicate the direction of fault movement (striations on right). Carbide lamp $12 \mathrm{~cm}$ high for scale.

off the far upper end of the cave that eventually dropped into a lower-level stream (McLuckie, 2002). Mapping showed that the new stream passage extended right under many of the long-known passages in the cave. This was quite unexpected, because the formerly known passages are located almost at the bottom of the local Helderberg limestones (Silurian-Devonian). These limestones are underlain by the thin dolomitic shale of the Brayman Formation, and it is in that formation that the stream

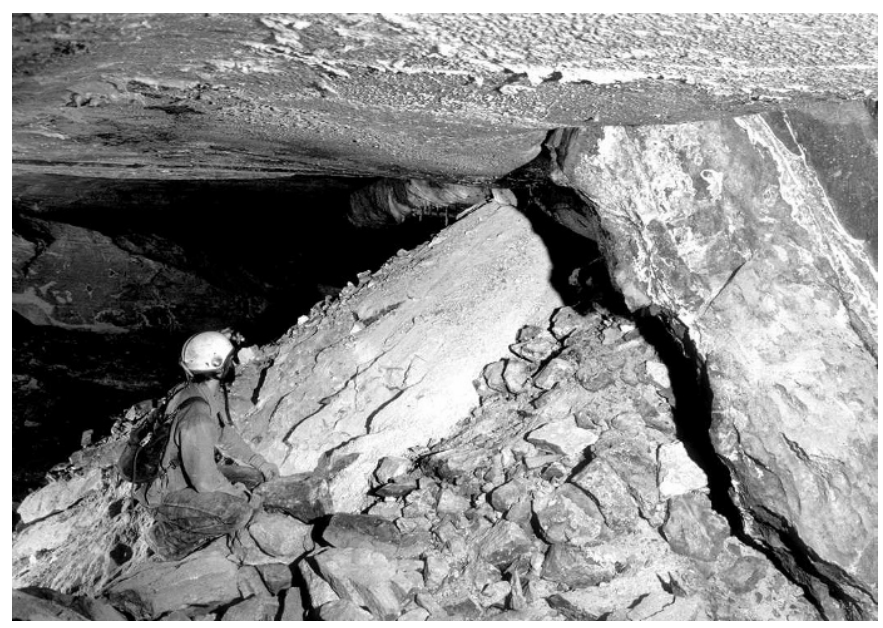

Figure 10. Cone of debris from the active fault zone in Ellison Cave, Georgia. 


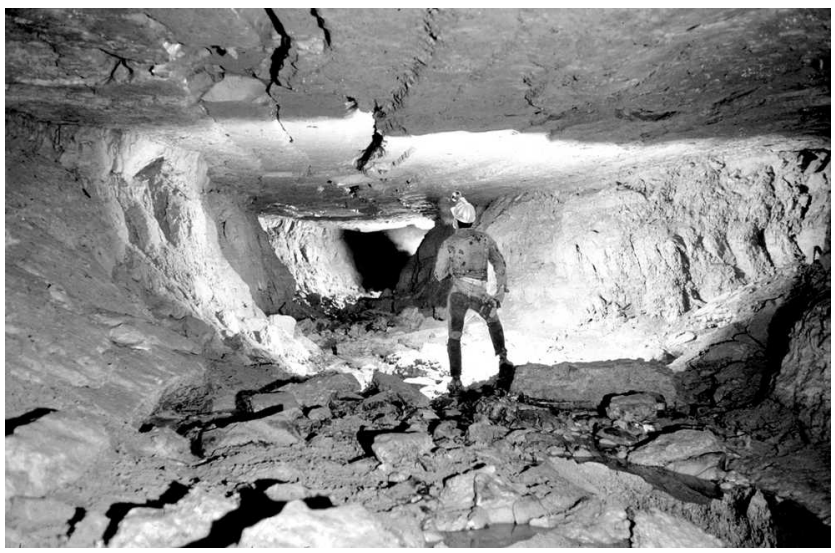

Figure 11. Example of a "contact cave," Ludington Cave, W.Va. The ceiling is at the base of the Hillsdale Limestone (Greenbrier Group), but the rest of the passage is in the Maccrady Shale.

passage is located. It is the only known cave passage to have formed entirely in the Brayman Formation. A close view shows that the passage formed along a low-angle thrust fault, which allowed enough water to pass through the poorly soluble rock to form a cave passage. The
Brayman Formation contains as much as $70 \%$ carbonate material in places, but it is soft, crumbly, and generally low in soluble material. The idea that it could be the primary host to an active cave stream had never been considered.

\section{Hidden Geochemical Processes}

Camp's Gulf Cave is located in the Cumberland Plateau of eastern Tennessee, near the western edge of the Appalachian Plateaus. It had been long known as a short cave that terminated in breakdown. In the late 1970s, local caver Bill Walter probed through the breakdown and discovered a large stream passage interrupted by a series of huge collapse chambers, three of which were, at that time, the largest cave rooms in the eastern United States. A later discovery in nearby Rumbling Falls Cave (Smith, 2002) contains an even larger room, up to $130 \mathrm{~m}$ by $220 \mathrm{~m}$ in horizontal extent and $110 \mathrm{~m}$ in total height. Figure 14 shows the top of this room, which is entered by a 62-m breakdown shaft.

The large room sizes are the result of local collapse of the Monteagle and Bangor Limestones into wide stream passages. As blocks fell, they were partly dissolved and eroded away by the action of the underground stream.

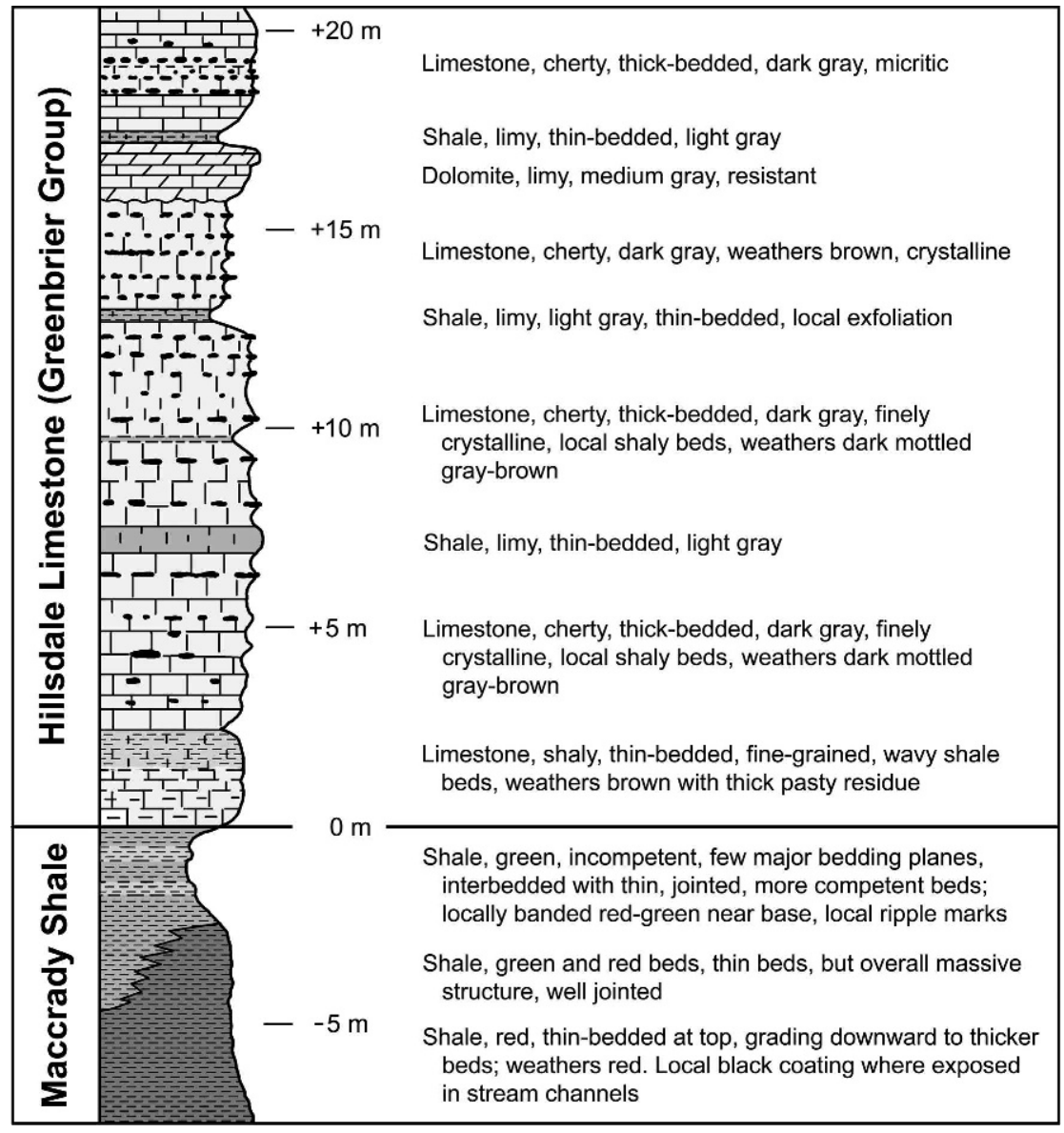

Figure 12. Stratigraphic column measured in Ludington Cave (Palmer, 1974). 

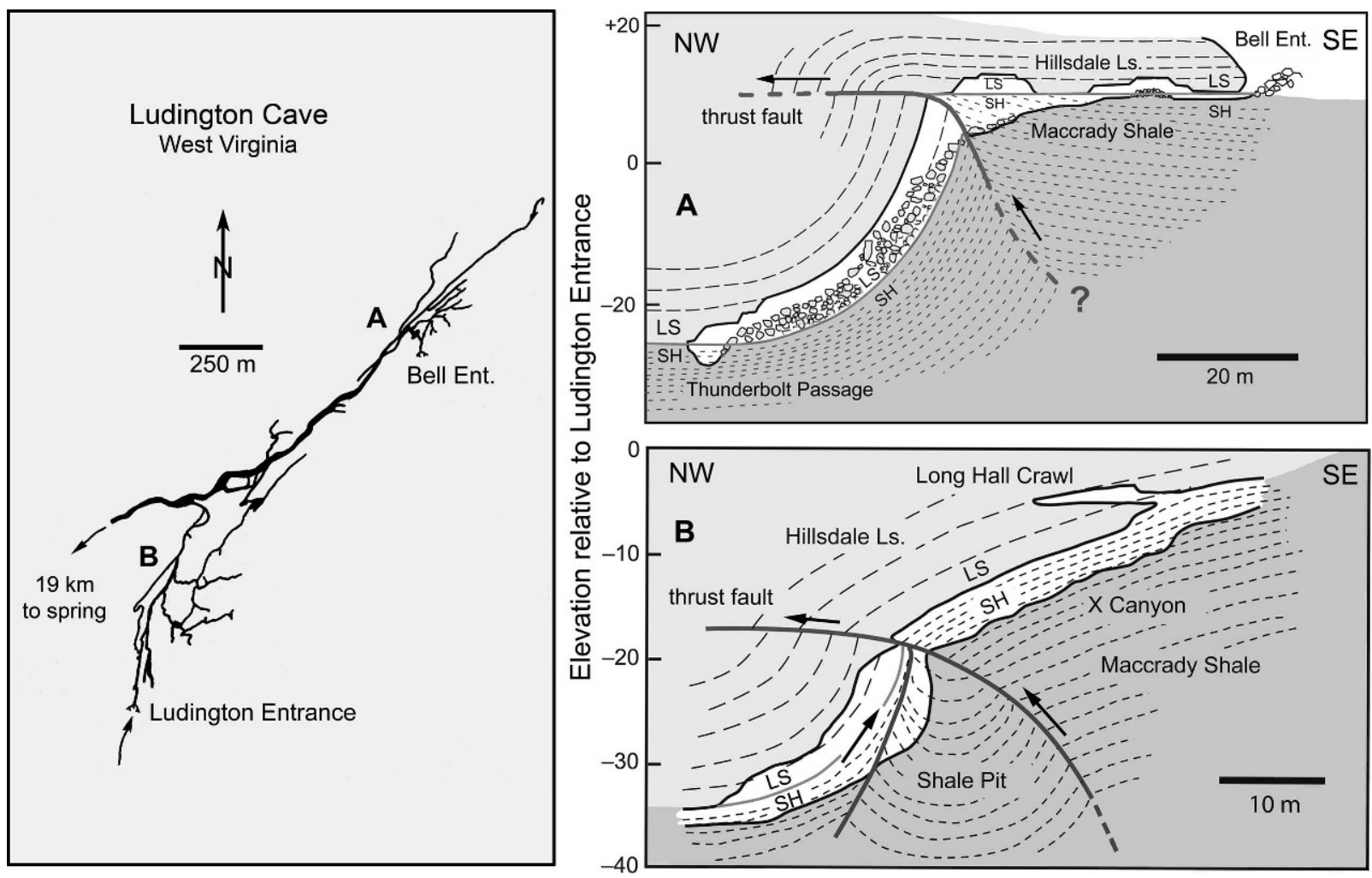

Figure 13. Representative cross sections through Ludington Cave showing fault disruption along the contact between the Hillsdale Limestone and the underlying Maccrady Shale.

Ordinarily, such massive collapse would produce a surface sinkhole. In this region, however, the limestone is capped by up to $100 \mathrm{~m}$ of Pennsylvanian sandstones and conglomerates. The net result is that only the very largest collapses are able to penetrate upward through the insoluble cap. These large rooms have been preserved more or less intact, with no surface expression.

The huge amount of collapse in these Tennessee caves has exposed sections of bedrock that have never been attacked by weathering, stream erosion, or even by caverelated dissolution. These sheltered rocks provide a view of geochemical processes that are rarely visible at the surface. Certain beds exposed in the walls of the rooms contain white, ghost-like shapes up to a meter in diameter (Fig. 14). Closer inspection shows that they are rounded nodules and thin dikes of gypsum (Fig. 15). These examples of primary gypsum are of special interest, because they indicate a highly evaporative depositional environment for the host limestone. This gypsum can be dissolved by vadose seepage and deposited lower in the caves as speleothems (gypsum flowers, etc.). On the other hand, most gypsum speleothems in these and other caves are composed of secondary gypsum, that is, gypsum deposited by the reaction between sulfuric acid and limestone. Reduction of gypsum in low-oxygen environments produces sulfides, either hydrogen sulfide gas or solid iron sulfides such as pyrite. When the sulfides are exposed to oxygen-rich water, they oxidize to sulfuric acid, which attacks the neighboring carbonate rock and converts it into secondary gypsum. The bases of many gypsum flowers contain blobs of iron oxide that indicate oxidation of pyrite in the exposed bedrock. Sulfur isotopic ratios $\left(\delta^{34} \mathrm{~S}\right)$ tend to be positive in primary marine sulfates and negative in secondary sulfates formed by the sulfuric acid reaction (Palmer, 2007, p. 129).

In many places, the primary gypsum has been replaced by quartz or calcite (Fig. 16; Palmer and Palmer, 1991). Replacement by calcite is well understood. As fresh water infiltrates through the limestone, the water becomes saturated with respect to calcite. When it encounters gypsum, that rock dissolves rapidly. The uptake of calcium ions makes the water supersaturated with respect to calcite, and calcite is forced to precipitate. Replacement of gypsum by quartz is more difficult to explain. Quartz and other forms of silica are most soluble (as silicic acid, $\mathrm{H}_{4} \mathrm{SiO}_{4}$ ) at $\mathrm{pH}$ values greater than about 8.5. Such high $\mathrm{pH}$ values can result from any of several processes, but in this region, it is commonly produced by water seeping through insoluble rocks and encountering carbonate rocks at depth in a rather closed environment; as the carbonates dissolve, the $\mathrm{CO}_{2}$ content of the water is depleted because there is no ready transfer of $\mathrm{CO}_{2}$ from the soil (Palmer, 2007). If the water encounters sources of acid, much of the silica precipitates. A possible mechanism to account for this process is reduction of some of the gypsum to hydrogen 

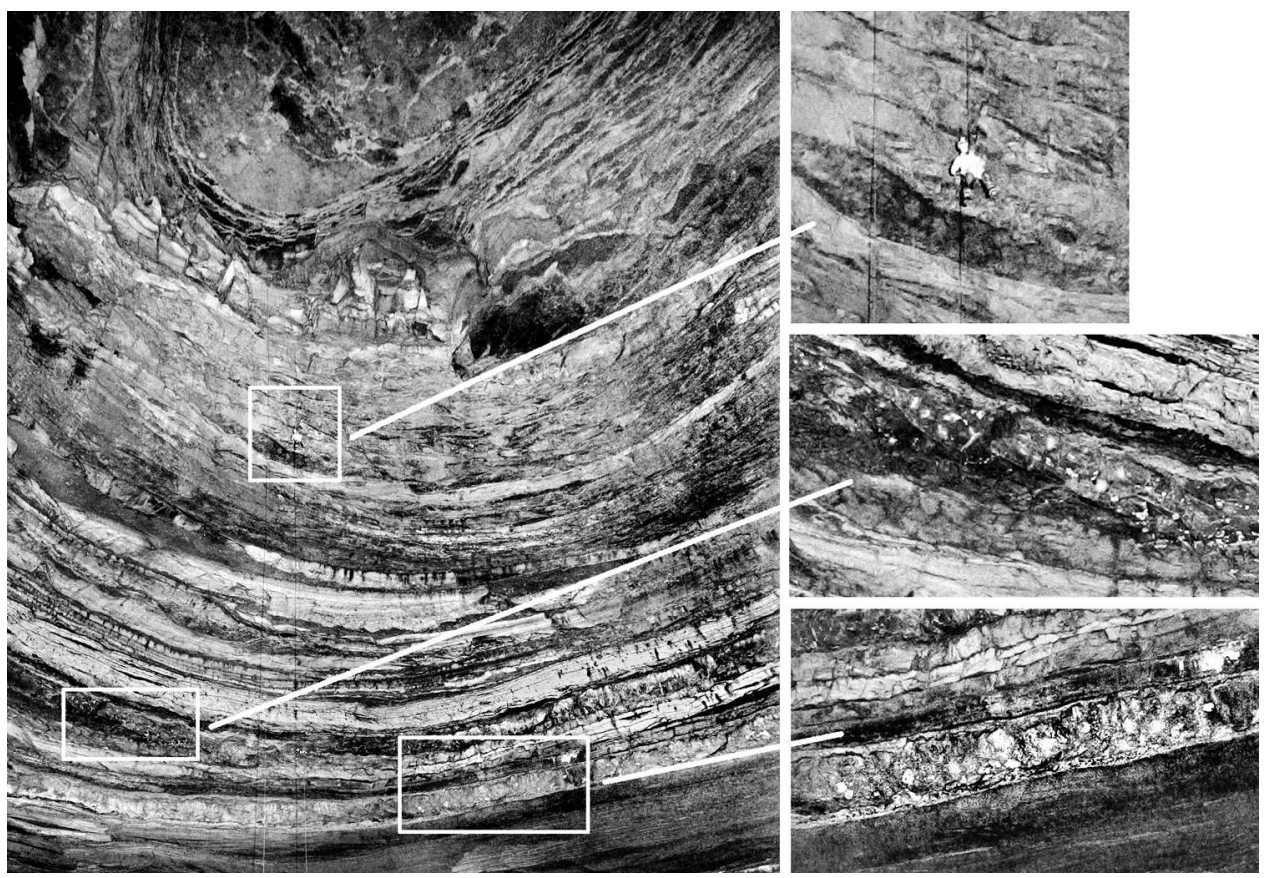

Figure 14. Upper part of a large breakdown room in Rumbling Falls Cave, Tennessee. The insets show enlargements of zones of gypsum nodules and (for scale) a person descending a rope.

sulfide, which produces neutral or possibly slightly acidic conditions. When the silica-rich high-pH water encounters the sulfate zones with their lower $\mathrm{pH}$, silica can precipitate. These are processes that are rarely observed at the surface, especially in humid climates such as those of the Appalachians.

\section{The Maze-Cave Debate}

The Appalachians contain some classic examples of maze caves (Palmer, 1975; White, 1976). They are scattered throughout the Appalachians, but the largest are extensive networks in the Plateaus and in low-dip parts of the Ridge

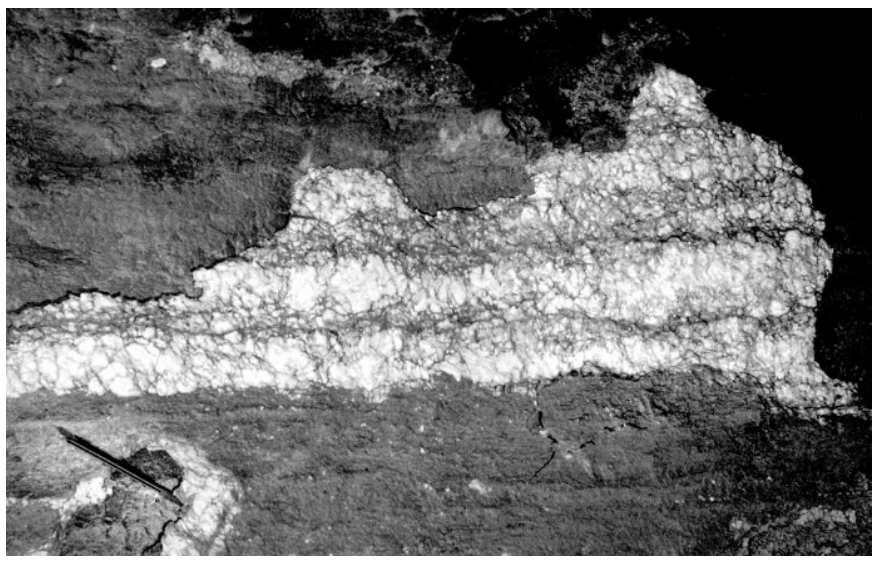

Figure 15. A dike of primary gypsum in Camp's Gulf Cave, Tennessee. Pen for scale at lower left. and Valley Province. These include America's quintessential network maze, Anvil Cave in Alabama, with $20.4 \mathrm{~km}$ of mapped passages. The Ridge and Valley Province in Pennsylvania and Virginia is particularly rich in network caves (see maps in Stone, 1953, and Douglas, 1964; see Figs. 17 and 18). Maze caves have been attributed to a variety of processes, including floodwater, diffuse seepage through an insoluble caprock, and hypogenic processes (Palmer, 1991, 2007). Their origins are of interest because they provide insight about the nature of groundwater

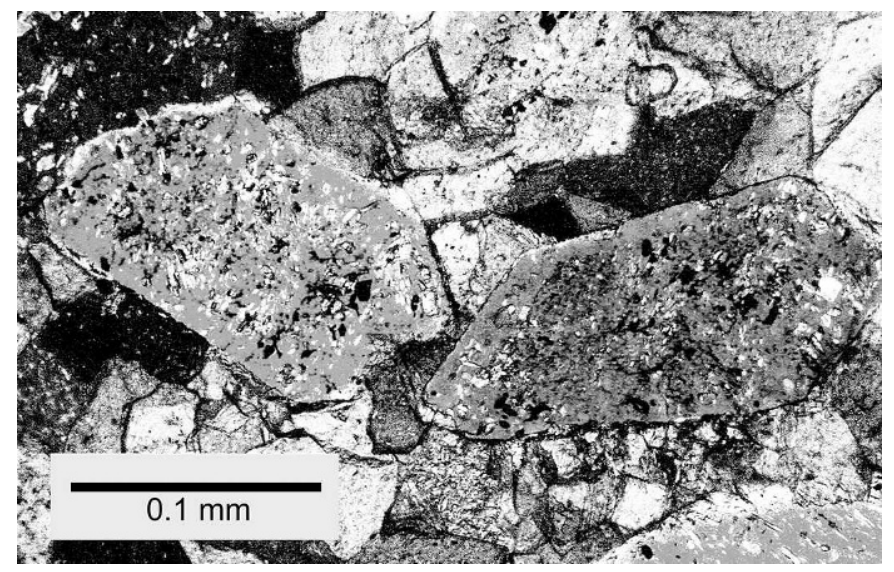

Figure 16. Thin section from a gypsum nodule in Camp's Gulf Cave, Tennessee, showing local quartz replacement. The large blocky speckled crystals are quartz, and the scattered stick-like inclusions in the quartz are residual bits of anhydrite. The crystals surrounding the quartz are gypsum.

Journal of Cave and Karst Studies, December 2009•189 


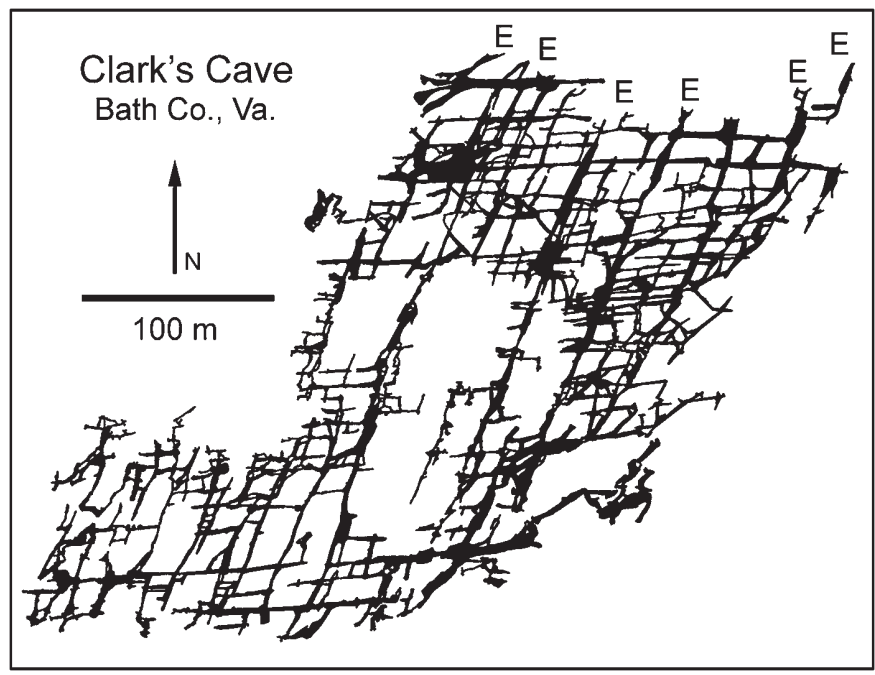

Figure 17. An example of a typical large Appalachian network maze: Clark's Cave, Virginia (based on map by Rod Morris).

hydraulics and chemistry. The largest network mazes in the Appalachians are capped by thin permeable sandstone. In active maze caves, the origin may be clear, but there are many inactive examples in the Appalachians whose origins are a matter of debate. Only the large sandstone-capped mazes are discussed here.

The lower Devonian limestones are particularly rich in network caves where there is a cap of Oriskany Formation (mainly sandstone). Examples include Paxton Cave, Helictite Cave, Clark's Cave, and Crossroads Cave in Virginia and Hamilton Cave in West Virginia. Anvil Cave, Alabama, is the largest example of all, although it is in Mississippian strata. Palmer (1975) proposed that they formed by diffuse, aggressive seepage through the thin, permeable caprock, while the governing effect of the sandstone allocated similar amounts of flow to each underlying fissure, regardless of its size.

Varnedoe (1964) attributed the origin of Anvil Cave to artesian groundwater confined by the local cap of Hartselle Sandstone (Mississippian). Maze caves in the Pennsylvanianage Vanport Limestone of western Pennsylvania include Harlansburg Cave, longest in the state with $7 \mathrm{~km}$ of surveyed passages. White $(1969,1976)$ explains them as the product of confined flow in the thin carbonate aquifers sandwiched between insoluble beds, combined with seepage from above. For these same Vanport caves, Fawley and Long (1997) and Christenson (1999) suggest a variety of origins, including that of White, as well as the release of sulfuric acid by oxidation of pyrite in organic-rich overlying beds.

The fact that these caves cluster at and just below a sandstone-limestone contact suggests that many or most are produced by water descending through the sandstone. Maze caves are rare or absent where the caprock is thick or contains low-permeability shale. Most such caves also

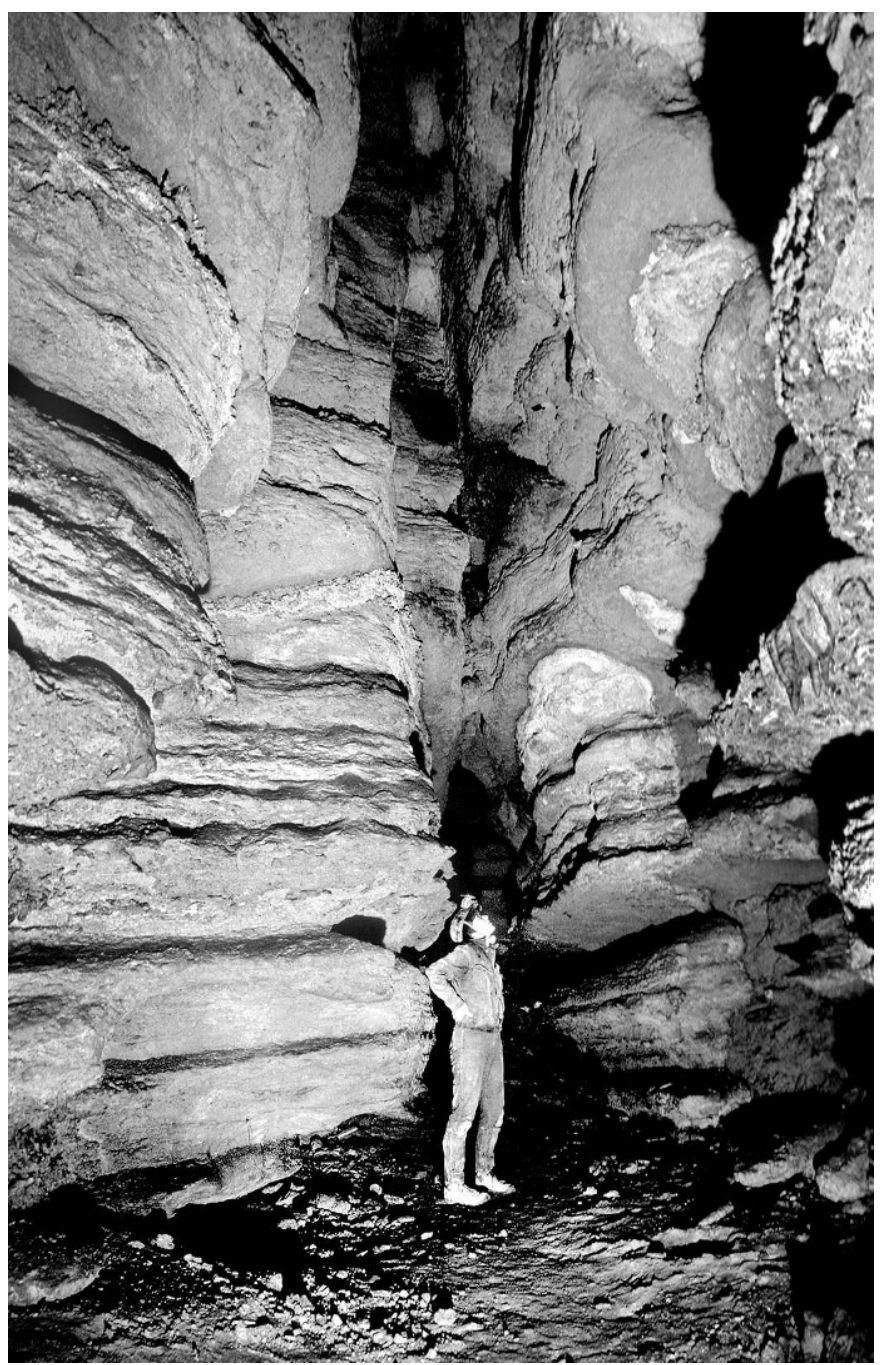

Figure 18. Fissure passage in Clark's Cave, Virginia.

show evidence for backflooding from nearby rivers. Although it is likely that much of the enlargement took place by flooding, it is equally probable that their initial dissolution was the result of diffuse recharge through the overlying caprock. Many such caves receive active drips through the overlying sandstone. This does not prove that the caves formed by this mechanism, but this hypothesis cannot be dismissed without close examination.

Klimchouk (2007) suggests instead that these caves were formed by water rising across the strata from below (Fig. 19). There is some support for this hypothesis. Rising water is common beneath valleys, and long periods of time are available for this flow to enlarge fissures in the soluble rock. However, this hypothesis has limitations in the Appalachian limestones. The water must pass through large sections of largely insoluble rock, much of which is shale with a permeability many orders of magnitude lower than that of the sandstone caprock. To form significant caves, seepage through shale with typical permeabilities of $10^{-5}$ to $10^{-9} \mathrm{~cm} \mathrm{~s}^{-1}$ would require hundreds of millions of years. 


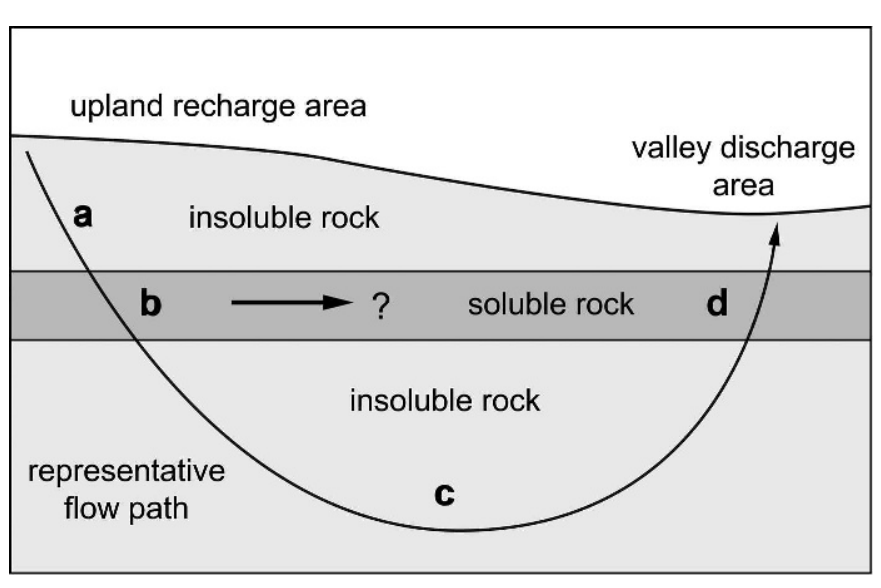

Figure 19. Contrasting models of maze-cave genesis. Palmer (1975) considers that Appalachian network caves capped by thin permeable sandstone are formed by diffuse seepage through the insoluble cap. An increase in flow through the soluble rock results in most water following paths such as ab-d. Recharge through the cap-rock delivers rather uniform amounts of flow to each fissure. Klimchouk (2007) considers that network caves are formed by deep groundwater rising through the soluble rock (paths such as a-b-c-d), and that the surrounding insoluble rocks limit the flow so that each opening enlarges at uniform rates.

Also, it is unlikely that the rising water would have any solutional capacity at all. In Figure 19, not only has the groundwater passed through the soluble aquifer on the way down, but it has undoubtedly encountered considerable carbonate as impurities in the surrounding sedimentary rocks. Field data from wells and caves show that most seepage water of this kind will have become saturated with respect to calcite while it is still descending. This water becomes warmer with depth because of the Earth's thermal gradient, an average of about $25{ }^{\circ} \mathrm{C}$ for every kilometer of depth. Even a small rise in temperature will drive the water to supersaturation with calcite. Some calcite may precipitate, which forces most water to follow shallower paths. The water does not reach equilibrium with calcite, however, because a certain threshold supersaturation must be present to allow precipitation to occur. Thus, as the water begins to rise and cool, time is required for the water to become aggressive toward calcite once more. Whether caves can form by rising water or by descending water requires an analysis specific to each cave, based on quantitative field data.

Debates such as this are welcome, because regardless of their outcome, they lead to a deeper understanding of cave origin. Perhaps no other karst region but the Appalachians offers such a variety of field conditions to fuel these debates.

\section{Changing Strategies in Cave Exploration}

Although geologists appreciate the basic data provided by cave explorers and mappers, the benefit also reflects back to the cavers themselves, even to those with no scientific training or interest in abstract hypotheses. Records from fifty years ago show that many people searched for caves without even knowing which rocks are soluble or where they occur. Since then, a basic knowledge of cave-related geology has spread through the speleological community.

Today a great deal of time and effort is invested in digging open new caves or passages, and cavers try to optimize their chance of success by applying geologic principles. Digging is most intense in the Northeastern states, where caves are scant and access points tend to be clogged with glacial deposits. Cave diggers soon become familiar with the local stratigraphy and know the structural properties of the various beds better than most geologists. On one occasion in New York, this knowledge allowed the local diggers to rescue a trapped caver who could easily have perished without their specific skills.

An early digging success was the opening of the spring exit of Single X Cave, in Schoharie County, New York (Mylroie, 1977). This cave contains $900 \mathrm{~m}$ of mapped passages and one of the largest cave rooms in the state. It terminates upstream in a single fissure passage almost 600$\mathrm{m}$-long and up to 30-m-high. Atypically, the excavation was done by a geologist as part of the field work for his Ph.D. dissertation. Most current diggers are non-academic. Their first major success was at Barrack Zourie Cave, also in Schoharie County, New York, and presently third longest in the state at 5.2-km-long (Hopkins et al., 1996; Dumont, 1995). This required a 10-m excavation along a vertical fissure clogged with glacial sediment.

Recently, the digging team of Barrack Zourie fame discovered a large cave farther east that required them to widen a narrow vertical fissure in shaly limestone for about $30 \mathrm{~m}$. The project nearly stalled at a particularly resistant bed, but experience told them that this was the key to entering highly soluble limestone below. A special effort put them through this barrier, and the cave opened into what promised to be one of the largest in the Northeast (Armstrong et al., 2007). To date, several kilometers have been explored. Exploration strategies rely strongly on the team's interpretation of local geology. Fracture patterns, base level, hydraulic conditions, and relationships between cave trends and stratal dip are topics of continual discussion among the group, and some of the most perceptive comments have come from cavers with no formal background in those fields. It is appropriate that they benefit from the geological knowledge to which they contribute so much.

\section{Conclusion}

Appalachian caves have provided considerable information about subsurface geologic structure, geochemistry, and hydrology, as well as speleogenesis and karst geomorphology. These topics are useful in a variety of

Journal of Cave and Karst Studies, December 2009•191 
disciplines, including the exploration for new caves. Many of the subjects introduced in this paper have barely been touched. These include the use of cave data as a guide to the development of wells and to the assessment of potential contaminant transport, quantitative validation of hypotheses for maze-cave origin, and interpretation of geochemical processes that are rarely seen at the surface.

\section{ACKNOWLEDGMENTS}

Many thanks to Margaret V. Palmer for her collaboration in examining the caves described in this paper, and to Yongli Gao of East Tennessee State University for inviting me to present this paper at the Second Appalachian Karst Symposium in May 2008. The suggestions of William Mixon and two anonymous reviewers have been very helpful.

\section{REFERENCES}

Armstrong, J., Barton, B., Barton, T., Chu, M., Folsom, M., Hopkins, T., Kuntz, J., Miller, B., Siemion, J., Taylor, B., and Whittemore, M., 2007, Breakthrough at Thunder Hole: The Northeastern Caver, v. 38, no. 4 , p. $112-126$.

Christenson, K., 1999, Comments on the speleogenesis of Vanport caves: $\mathrm{GEO}^{2}$, v. 26 , no. $2-3$, p. $17-20$.

Davies, W.E., 1958, Caverns of West Virginia: West Virginia Geological and Economic Survey, v. 19A, 330 p.

Dasher, G., ed., 2000, The Caves of East-Central West Virginia, Barrackville, W.Va., West Virginia Speleological Survey Bulletin 14, $295 \mathrm{p}$.

Douglas, H.H., 1964, Caves of Virginia, Falls Church, Va., Virginia Cave Survey, $761 \mathrm{p}$.

Dumont, K.A., 1995, Karst hydrology and geomorphology of the Barrack Zourie Cave System, Schoharie County, New York [M.S. thesis]: Mississippi State, Miss., Mississippi State University, reprinted as New York Cave Survey, Bulletin 5, $71 \mathrm{p}$.

Fawley, J.P., and Long, K.M., 1997, Harlansburg Cave: The longest cave in Pennsylvania: Journal of Cave and Karst Studies, v. 59, no. 3, p. 106-111.

Fetter, C.W., 2001, Applied Hydrogeology (4th edition): Upper Saddle River, N.J., Prentice-Hall, 598 p.

Haar, D., Medville, D., and Werner, E., eds., 1975, Caves and karst of Monroe County, West Virginia, Pittsburgh, Pa., West Virginia Speleological Survey Bulletin 4, 151 p. +3 plates.
Hopkins, T., Nelson, A., Shiner, K., and Engel, T., 1996, Barrack Zourie: A digger's dream: NSS News, v. 54, no. 4, p. 90-97.

Kambesis, P., 2007, The importance of cave exploration to scientific research: Journal of Cave and Karst Studies, v. 69, no. 1, p. 46-58.

Klimchouk, A.B., 2007, Hypogene speleogenesis: Hydrogeological and morphogenetic perspective, Carlsbad, N.M., National Cave and Karst Research Institute Special Paper 1, 106 p.

McLuckie, S., 2002, Recent extensions to Knox Cave [abs.]: Journal of Cave and Karst Studies, v. 64, no. 3, 190 p.

Mylroie, J.E., 1977, Speleogenesis and karst geomorphology of the Helderberg Plateau, Schoharie County, New York [Ph.D. thesis]: Troy, N.Y., Rensselaer Polytechnic Institute, reprinted as New York Cave Survey Bulletin 2, 336 p.

Nardacci, M., ed., 1991, Guide to the caves and karst of the Northeast: Huntsville, Alabama, National Speleological Society, 167 p.

Palmer, A.N., 1974, Geologic influence upon cave-passage orientation in Ludington Cave, Greenbrier County, West Virginia, in Proceedings, Fourth Conference on Karst Geology and Hydrology: Morgantown, W. Va., West Virginia Geological and Economic Survey, p. 33-40.

Palmer, A.N., 1975, The origin of maze caves: NSS Bulletin, v. 37, no. 3, p. $56-76$.

Palmer, A.N., 1991, Origin and morphology of limestone caves: Geological Society of America Bulletin, v. 103, no. 1, p. 1-21.

Palmer, A.N., 1999, Patterns of dissolution porosity in carbonate rocks, in Palmer, A.N., Palmer, M.V., and Sasowsky, I.D., eds., Karst modeling: Charles Town, W.Va., Karst Waters Institute, Special Publication 5, p. 71-78.

Palmer, A.N., 2007, Cave Geology: Dayton, Ohio, Cave Books, 454 p.

Palmer, A.N., and Palmer, M.V., 1991, Replacement mechanisms among carbonates, sulfates, and silica in karst environments: Some Appalachian examples, in Kastning, E.H., and Kastning, K.M., eds., Appalachian Karst: Proceedings of the Appalachian Karst Symposium, Radford, Virginia, March 23-26, 1991: Huntsville, Ala., National Speleological Society, p. 109-115.

Porter, C.O., 2002, Adirondack caves, Huntsville, Ala., National Speleological Society, post-convention field camp guidebook, $20 \mathrm{p}$.

Schreiber, R., 1969, 510 feet is Fantastic: NSS News, v. 27, no. 1, p. $10-16$.

Smith, M.O., 2002, Rumbling Falls Cave [abs.]: Journal of Cave and Karst Studies, v. 64, no. 3, 190 p.

Stone, R.W., 1953, Caves of Pennsylvania: The American Caver (Bulletin of the National Speleological Society), v. 15, 143 p.

Varnedoe, W.W., 1964, The formation of an extensive maze cave in Alabama: Alabama Academy of Science Journal, v. 35, no. 4, p. $143-148$.

Varnedoe, W.W., 1973, Alabama caves and caverns: Huntsville, Ala., Alabama Cave Survey, 1375 p.

White, W.B., 1969, Conceptual models of carbonate aquifers: Ground Water, v. 7, no. 3, p. 15-21.

White, W.B., 1976, The caves of western Pennsylvania: Pittsburgh, Pa., Pennsylvania Geological Survey, General Geology Report 67, 98 p. 